\title{
Regeneration of manganese electrolyte during continuous electrolysis of manganese coatings
}

\author{
Algirdas Šulčius \\ Department of Physical and \\ Inorganic Chemistry, \\ Kaunas University of Technology, \\ Radvilenu Rd. 19, \\ 50254 Kaunas, Lithuania
}

\begin{abstract}
Water pollution in the electrolytic manganese metal (EMM) industrial production process is a serious problem, and the manganese and ammonia nitrogen concentration in the rivers near EMM plants still exceeds the standards. An environment-friendly regeneration method of the manganese electrolyte (ME) that reduces the duration of the electrodeposition process and saves water resources for ME preparation in laboratories was proposed. Thus, electrolytic manganese metal powder (EMMP) was dissolved in ME and the addition of hydroxylamine sulphate altered significantly the dissolution effect of EMMP in ME. The provided ME regeneration scheme allows to extend duration of the Mn coating deposition process up to one week without changing ME, just only adding the electrolyte prepared by dissolving EMMP in an anolyte. EMMP losses did not exceed 5-7\% from the mass of the electrodeposited Mn coatings on the cathode. Ammonium selenate was dissolved in ME by periodically dissolving $2 \%$ of the salt from the mass of the electrodeposited $\mathrm{Mn}$ coating on the cathode at an electrolyte temperature of $30-40^{\circ} \mathrm{C}$.
\end{abstract}

Keywords: electrolytic manganese, manganese powder, hydroxylamine sulphate, electrolyte regeneration

\section{INTRODUCTION}

Electrolysis of aqueous solutions is widely used in metallurgical technology. The electrolytic manganese metal (EMM) is mainly produced through aqueous electrolysis [1-5. EMM is an important alloying element [6] in the stainless steel industry, especially for production of low-carbon steels, and in nonferrous alloys [⿰亻]丁. It is reported that about $90 \%$ of EMM [8] is used for these purposes. In industry EMM in most cases is produced from ammonium sulphate media using ammonium sulphate on stainless steel sheets [9-11]. Although many types of additives have been reported [12-15], selenium containing compounds such as selenous acid, $\mathrm{H}_{2} \mathrm{SeO}_{3}$, ammonium selenate, $\left(\mathrm{NH}_{4}\right)_{2} \mathrm{SeO}_{4}$ and $\mathrm{SeO}_{2}$ remain to be widely used because of their high efficiency. Currently studies on nonselenium additives are being investigated [16-17], with respect to environmental problems, but $\mathrm{SeO}_{2}$ still remains to be widely used as a relatively low-cost additive in the EMM industry.

\footnotetext{
${ }^{*}$ Corresponding author. Email: algirdas.sulcius@ktu.lt
}

Since China is the largest producer and exporter of EMM, in China the EMM industrial production process has been a serious problem because of water pollution [18]. It is reported that, in order to produce $1 \mathrm{t}$ of EMM, approximately $1-3 t$ of wastewater are discharged into the environment [19]. Therefore the manganese and ammonia nitrogen concentrations in the rivers near to EMM plants still exceed the standards.

From the territory of Lithuania, the highest pollution to the Baltic Sea comes from the Nemunas River runoff: an average of 40.5 thousand $t$ per year of total nitrogen ( $85 \%$ of the total amount of nitrogen originating in rivers entering the Lithuanian part of the Baltic Sea) [20], of which waste from wastewater treatment plants accounts for 3.5\%. Assessing the qualitative indicator of the concentrations of hazardous substances in the marine environment has revealed that Lithuania's Baltic Sea is not in a good condition, and heavy metals (especially $\mathrm{Cu}, \mathrm{Pb}, \mathrm{Zn}, \mathrm{Ni}, \mathrm{Mn}$ ) exceeding the environmental quality standards in the Baltic Sea sediments indicate a long-term negative impact of these pollutants on the marine environment. In order to address 
the problem of eutrophication, the Baltic Sea Commission on Environment (HELCOM) has set nitrogen targets for each country. Lithuania by signing the declaration of the HELCOM Ministerial Meeting, held on 3 October 2013 in Copenhagen, made the commitment to reduce the effluent of nitrogen by $8970 \mathrm{t}$ (19\%) to the Baltic Sea over the period of 1997-2003.

The aim of the investigation was to find an environment-friendly regeneration method of ME in a laboratory, reduce the duration of the manganese electrodeposition process and save water resources for manganese electrolyte preparation.

\section{EXPERIMENTAL}

\section{Electrolysis}

The electrolysis of the Mn coatings was investigated in a $25 \mathrm{~L}$ bath $(240 \times 240 \times 500 \mathrm{~mm})$, produced from PVC. For the electrodeposition of the $\mathrm{Mn}$ coatings the aqueous manganese electrolyte (ME) of the following composition was used: $170 \mathrm{~g} / \mathrm{L}$ ammonium sulphate $\left(\mathrm{NH}_{4}\right)_{2} \mathrm{SO}_{4}$ (Reakhim, 99.0\%), $180 \mathrm{~g} / \mathrm{L}$ manganese(II) sulphate $\left(\mathrm{MnSO}_{4} \times 5 \mathrm{H}_{2} \mathrm{O}\right.$, Reakhim, 99.0\%) and $0.5 \mathrm{~g} / \mathrm{L}_{\left(\mathrm{NH}_{4}\right)} \mathrm{SeO}_{4}$ (Reakhim, $99.0 \%)$. The $\mathrm{pH}$ of the produced electrolyte was 3.94.0; during the electrolysis at 6.9-7.0 and 2.4-2.5; $t=20-60^{\circ} \mathrm{C}$. The best quality, semi-glossy Mn coatings were obtained from the electrolyte with an $\left(\mathrm{NH}_{4}\right)_{2} \mathrm{SeO}_{4}$ additive of $0.5 \mathrm{~g} / \mathrm{L}$ concentration at $20-30^{\circ} \mathrm{C}$ and at a cathodic current density $\left(j_{c}\right)$ of $4-15 \mathrm{~A} / \mathrm{dm}^{2}$ (Fig. 1). The thickness of the electrodeposited Mn coatings was 20-40 $\mu \mathrm{m}$ at optimal current densities of 6-12 A/dm².

Mild carbon steel St-3 (GOST 380-94), equivalent to steel ASTM 570 grade 36, containing $0.22 \%$ C, $0.5 \% \mathrm{Mn}$, $0.1 \% \mathrm{Si}, 0.04 \% \mathrm{P}, 0.05 \% \mathrm{~S}$ plates with the square area $6.4 \mathrm{dm}^{2}$, was used as a cathode. The surfaces of the electrodes were polished using a felt wheel and the polishing paste Fareda Paste Compound G3, degreased by Vienna lime (mixture of
$60 \% \mathrm{CaO}$ and $40 \% \mathrm{MgO}$ powders) and dipped into a $2 \%$ solution of sulphuric acid. All chemicals were of analytically pure grade (Aldrich and Reakhim, Russia). Twice distilled water was used in the preparation of the solutions.

Four $\mathrm{Pb}-1 \% \mathrm{Ag}$ alloy plates [21-23] coated with a $\mathrm{MnO}_{2}$ film [24] were used as inert anodes. Such anodes are widely used in industry for electrodeposition of $\mathrm{Mn}$ and its alloy with $\mathrm{Ni}$ and $\mathrm{Zn}$ [25-26] coatings. They were produced by alloying $\mathrm{Pb}$ with $\mathrm{Ag}$ and a subsequent anodic pretreatment in manganese-ammonium sulphate electrolyte with a small amount of a $\mathrm{NH}_{4} \mathrm{Br}$ additive. PVC fabric diaphragms were used for separating cathodic and anodic compartments in the electrodeposition cell.

\section{Dissolution of EMM powder in ME}

$0.5 \mathrm{~g}$ of electrolytic manganese metal powder (EMMP) was dissolved in $200 \mathrm{~mL}$ of ME. The dissolution rate of the EMMP sample in the ME was determined by measuring the volume of evolved hydrogen using the scheme shown in Fig. 2. The dissolution duration until the complete dissolution of EMMP in ME and the transparency were also evaluated. EMMP was manufactured from flakes (diameter 3-4 cm, thickness 1-2 mm) of EMM Mн998 (Georgia, Mn 99.8\%, C $0.04 \%, \mathrm{P} 0.003 \%$, S $0.03 \%$ ) by milling in a vibrating disc mill Pulverisette 9 (milling bodies produced from WC). EMMP was passed through a sieve 016 with a diameter of $0.3 \mathrm{~mm}$. Only this EMMP fraction was used.

Hydrazine is used for production of Co from Co hydroxide [27]. But hydrazine is very poisonous and aggressive for environment. Therefore, an environment-friendly reducing agent hydroxylamine was chosen. Hydroxylamine salts were used to improve dissolution of EMMP in electrolytes, therefore, hydroxylamine sulphate (analytically pure grade, Reakhim, Russia) was selected. It is known that dilute aqueous solutions of hydroxylamine salts are stable, whereas concentrated ones (especially in the base medium) decompose into ammonia, nitrogen and dinitrogen oxide [28].

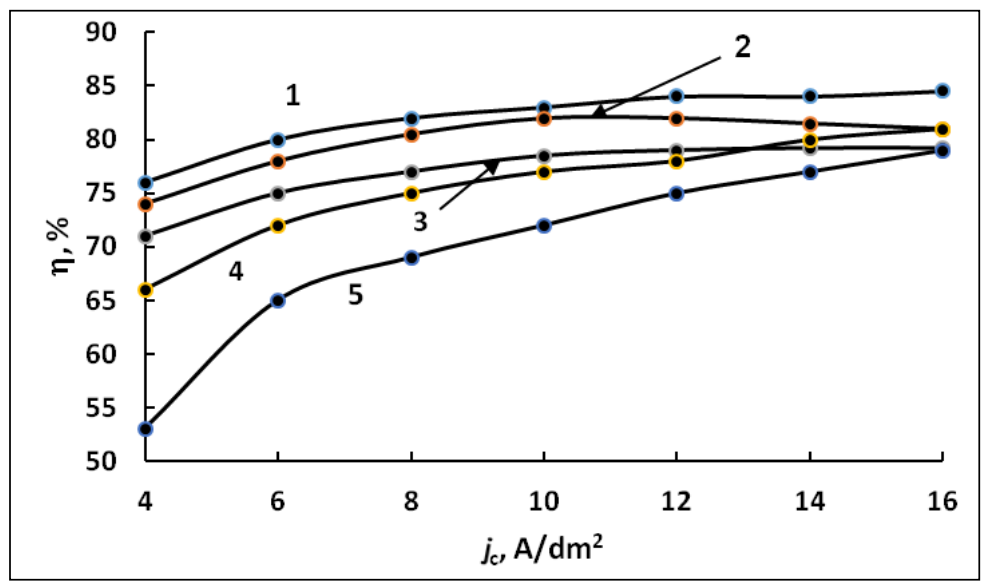

Fig. 1. The dependence of the manganese current efficiency on the cathode current density. The temperature of manganese electrolyte, ${ }^{\circ} \mathrm{C}: 1,20 ; 2,30 ; 3,40 ; 4,50 ; 5,60$ 


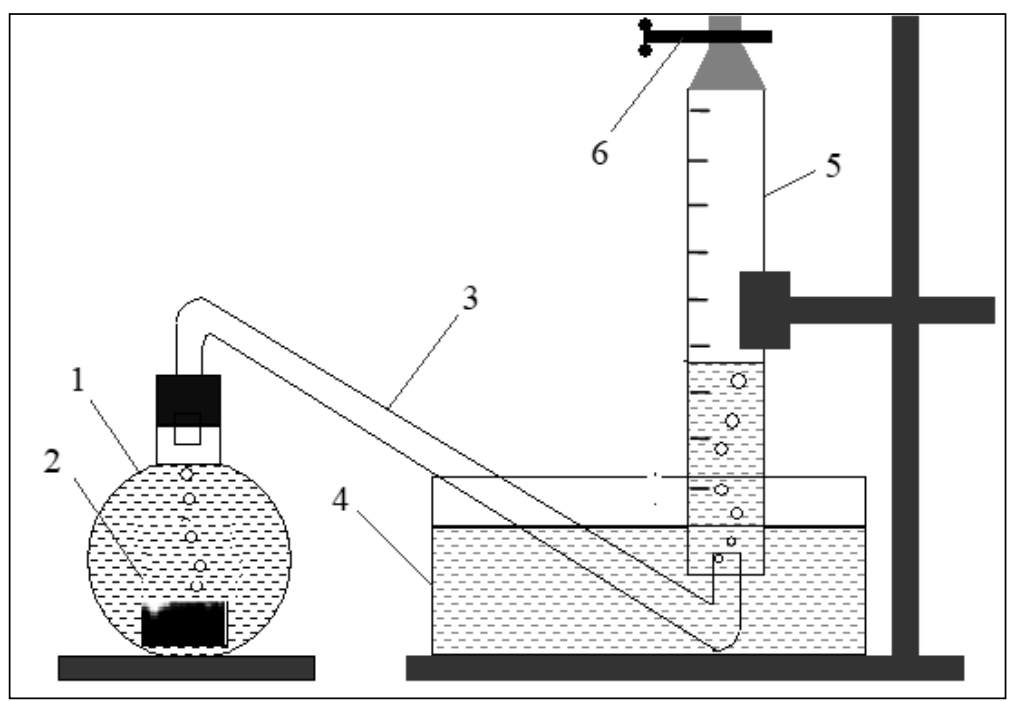

Fig. 2. The investigation scheme of EMMP dissolution in ME: 1, flask with manganese electrolyte; 2, EMMP; 3, tube; 4, crystallizer with water; 5 , burette; 6 , the hose, which is pressed with a clamp

\section{XRD and microhardness}

The structure of electrodeposits was investigated by XRD using a Bruker diffractometer (model D8 Advance), and diffraction patterns were identified using the PDF-2 database. The morphology and detailed elemental analysis of the surface of electrodeposits were investigated using a scanning electron microscope (SEM) with an energy dispersive X-ray (EDX) spectral analyser (Jeol model DSM-5400 LV).

The microhardness by Vickers $H V$ and the internal stresses $\sigma$ of Mn coatings were measured by the methods which were described in detail in the previous paper [12].

\section{RESULTS AND DISCUSSION}

\section{Dissolution of EMMP in manganese electrolyte}

It has been determined that the hydroxylamine additive slightly affects the $\mathrm{pH}$ of $\mathrm{ME}(\Delta \mathrm{pH} 0.2-0.3)$, but significantly altered the dissolution effect of EMMP, and was especially evident in the production of produced ME at $\mathrm{pH}$ 3.9-4.0. The amount of hydrogen released by dissolving EMMP was significantly reduced. However, this does not mean that the dissolution of EMMP has worsened. In contrast, EMMP in ME containing a hydroxylamine additive dissolved much faster than in electrolytes without a hydroxylamine additive. This can be explained by the fact that besides the main EMMP dissolution reactions in ME

$$
\begin{aligned}
& \mathrm{Mn}(\mathrm{s})+2 \mathrm{H}^{+}(\mathrm{aq}) \rightarrow \mathrm{Mn}^{2+}(\mathrm{aq})+\mathrm{H}_{2}(\mathrm{~g}), \\
& \mathrm{Mn}(\mathrm{s})+\mathrm{H}_{2} \mathrm{O}(\mathrm{l}) \rightarrow \mathrm{Mn}(\mathrm{OH})_{2}(\mathrm{~s})+\mathrm{H}_{2}(\mathrm{~g}),
\end{aligned}
$$

reaction without hydrogen emission occured:

$$
\begin{aligned}
& \mathrm{Mn}(\mathrm{s})+\mathrm{NH}_{2} \mathrm{OH}(\mathrm{aq})+2 \mathrm{H}^{+}(\mathrm{aq}) \rightarrow \mathrm{Mn}^{2+}(\mathrm{aq})+ \\
& \mathrm{NH}_{3}(\mathrm{~g})+\mathrm{H}_{2} \mathrm{O}(\mathrm{l}) .
\end{aligned}
$$

Ammonia take part in the formation of manganese-ammonia complexes [⿰亻也 or in the reaction with water, form ammonium ions:

$$
\begin{aligned}
& \mathrm{Mn}^{2+}(\mathrm{aq})+\mathrm{nNH}_{3}(\mathrm{~g}) \rightarrow\left[\mathrm{Mn}\left(\mathrm{NH}_{3}\right)_{\mathrm{n}}\right]^{2+}(\mathrm{aq})(1 \leq \mathrm{n} \leq 4),(4) \\
& \mathrm{NH}_{3} \cdot \mathrm{H}_{2} \mathrm{O}(\mathrm{aq}) \leftrightarrow \mathrm{NH}_{4}^{+}(\mathrm{aq})+\mathrm{OH}^{-}(\mathrm{aq}) .
\end{aligned}
$$

The electrolyte containing the hydroxylamine additive, after dissolving it in EMMP, was more transparent and contained less insoluble solids than the electrolyte without a hydroxylamine additive. Control of the concentration of the hydroxylamine sulphate additive in ME was unnecessary as its concentration decreased rapidly during the electrolysis. The effect of the hydroxylamine additive on the neutralization of EMMP in the neutral electrolyte was lower (less hydrogen was released), since part of hydroxylamine was used for the reduction of $\mathrm{Mn}^{2+}$ oxidation products to higher $\mathrm{Mn}$ valence compounds.

Increasing the amount of the hydroxylamine sulphate additive from 0.25 to $5.0 \mathrm{~g} / \mathrm{L}$ led to the decrease of the volume of evolved hydrogen and the total dissolution duration of the EMMP sample. This indicates an increase in the proportion of reaction 3 in the dissolution. This is especially evident in ME with $\mathrm{pH}$ 3.9-4.0 (Fig. 3).

Mn coatings can also be precipitated from an acidic ME at $\mathrm{pH}$ 2.5. Data on the dissolution of EMMP in an acidic electrolyte $\mathrm{pH} 2.5$ is provided in Fig. A. Only a slightly decrease in the total amount of soluble electrolytes was observed.

In a neutral electrolyte at $\mathrm{pH} 7.0$ (Fig. 5) and a hydroxylamine additive concentration of $0.25 \mathrm{~g} / \mathrm{L}$, the total mass of the additive was used to reduce the $\mathrm{Mn}$ (II) compounds, the passivity of the EMMP surface with air oxygen 


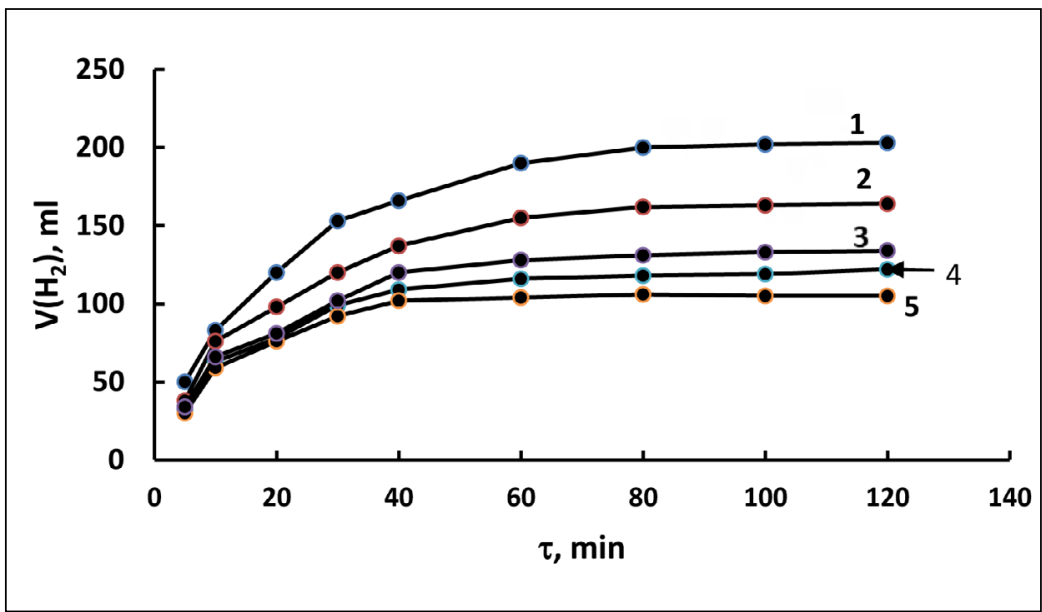

Fig. 3. Dependence of the hydrogen volume evolved on the duration of the EMMP dissolution in ME at $\mathrm{pH}=4.0$. Concentrations of ammonium selenate and hydroxylamine sulphate in $\mathrm{ME}, \mathrm{g} / \mathrm{L}: 1) 0.5+0$; 2) $0.5+0.25$; 3$) 0.5+1.25 ; 4) 0.5+2.5 ; 5) 0.5+5.0$

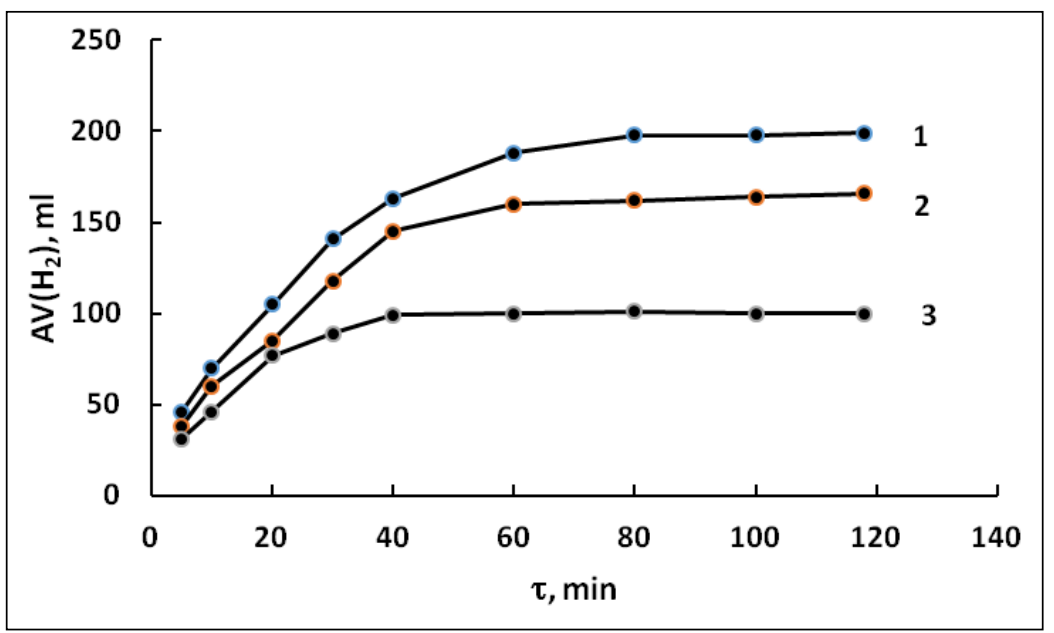

Fig. 4. Dependence of the hydrogen volume evolved on the duration of the EMMP dissolution in ME at $\mathrm{pH}=2.5$. Concentrations of ammonium selenate and hydroxylamine sulphate in $\mathrm{ME}, \mathrm{g} / \mathrm{L}: 1) 0.5+0$; 2) $0.5+1.25 ; 3) 0.5+5.0$

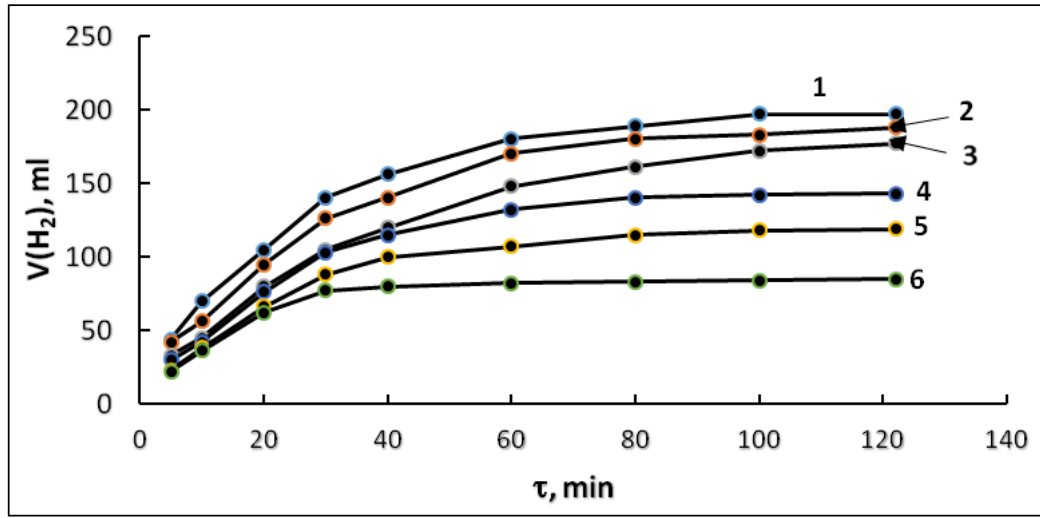

Fig. 5. Dependence of the hydrogen volume evolved on the duration of the EMMP dissolution in ME at $\mathrm{pH}=7.0$. Concentrations of ammonium selenate and hydroxylamine sulphate in $\mathrm{ME}, \mathrm{g} / \mathrm{L}: 1) 0+0$; 2) $0.50+0$; 3$) 0.5+0.25 ; 4) 0.5+1.25 ; 5) 0.5+2.5 ; 6) 0.5+5.0$ 
and the $\mathrm{pH}$ of the medium. Afterwards the process takes place in accordance with the equations of reactions 1 and 2. The author supposes that when the concentration of hydroxylamine sulphate in neutral electrolytes exceeded $1.0 \mathrm{~g} / \mathrm{L}$, the part of reaction 3 (EMMP dissolution process) increased and reactions $4-5$ could occur.

Based on the data provided above, it can be concluded that the addition of hydroxylamine sulphate affects the better dissolution of EMMP. The optimal concentration of hydroxylamine sulphate in acidic ME (pH 2.5) is $1.25 \mathrm{~g} / \mathrm{L}$, and in neutral ones ( $\mathrm{pH} 7.0$ ) it is $2.0 \mathrm{~g} / \mathrm{L}$. But the acidic ME was not subsequently investigated, because the current efficiency of the coatings is $6-10 \%$ lower than that of neutral electrolytes.

\section{Regeneration schemes}

It has been determined that for the electrodeposition of high quality manganese coatings the filter has been made from cotton fabric of medium density. The use of a denser fabric (flannel) is impossible due to blocking of pores with finely dispersed $\mathrm{Mn}(\mathrm{OH})_{2}$ and $\mathrm{MnO}_{2}$ residues of insoluble EMMP, and hydrogen bubbles. When one filtration element was used, cleaning of the filter clogged with the $\mathrm{Mn}(\mathrm{OH})_{2}$ or $\mathrm{MnO}_{2}$ precipitate took place for $\sim 2 \mathrm{~h}$, while the continuous electrolysis process discontinued.

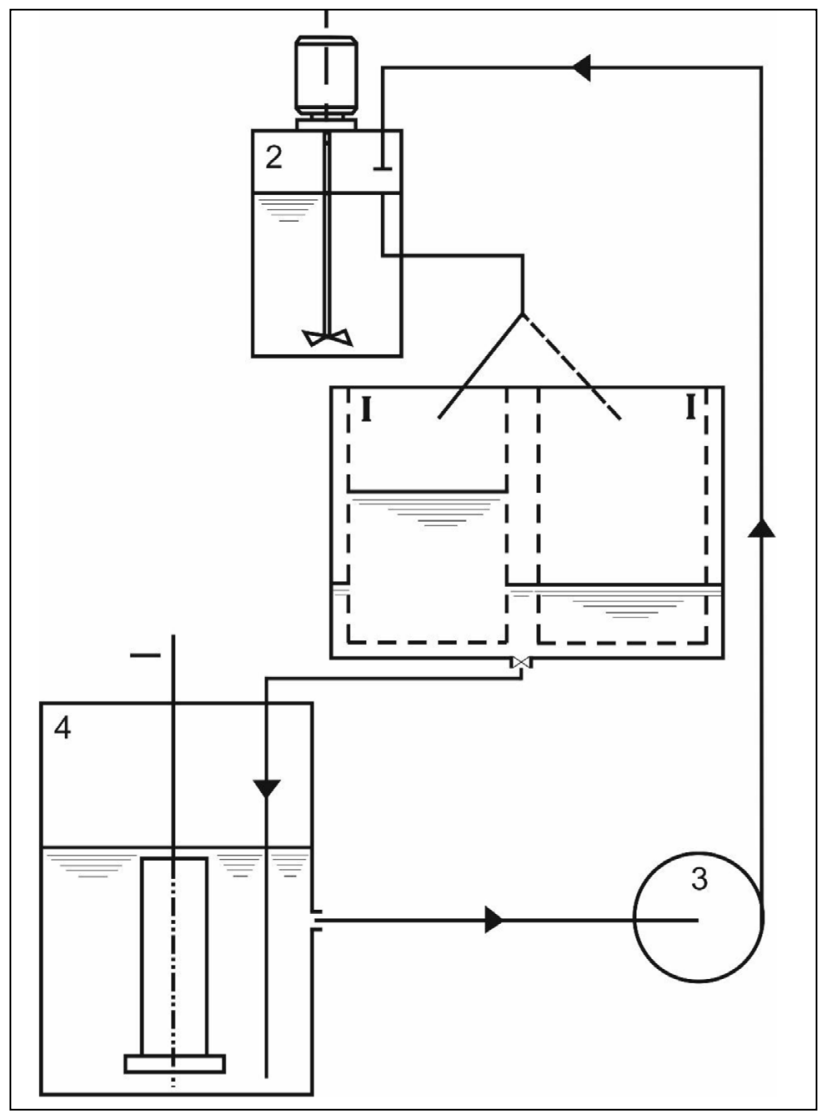

Fig. 6. Regeneration scheme 1: 1, filtration element; 2, regenerator; 3, pump; 4, electrolysis bath
Therefore, it was decided to perform regeneration with two filtration elements from the flannel fabric, so that it would be possible to work without problems with one or another filtration element 1 at the same time (Fig. 6). The operating time of one or another filtration element before it was blocked at electrolyte $\mathrm{pH}$ of 6-7 did not exceed 1 hour.

This was the challenge in the regeneration process and Mn coating electrodeposition. The main reason was the high $\mathrm{pH}$ value of the electrolyte in the regenerator, which allowed formation of slightly soluble manganese compounds in the electrolyte layer at the surface of the dissolved manganese. It is known that during electrolysis with insoluble $\mathrm{Pb}-$ $1 \%$ Ag alloy anodes, the electrolyte is acidified by the evolution of oxygen leading to the increase in the concentration of hydrogen ions. A new scheme (Fig. 7) was used in which an acidic electrolyte (anolyte) with $\mathrm{pH} 2.3$ was used to accelerate the dissolution of the added EMMP.

The new regeneration scheme allowed continuous electrolysis. The regenerator was comprised of a dish consisting of 7 sections connected by gaps. The first one was intended for EMMP dissolution in ME. The dissolution was carried out using a mechanical stirrer. The anolyte was pumped into this section. On the bottom of sections 2 to 4, EMMP and insoluble Mn products accumulated on the bottom of

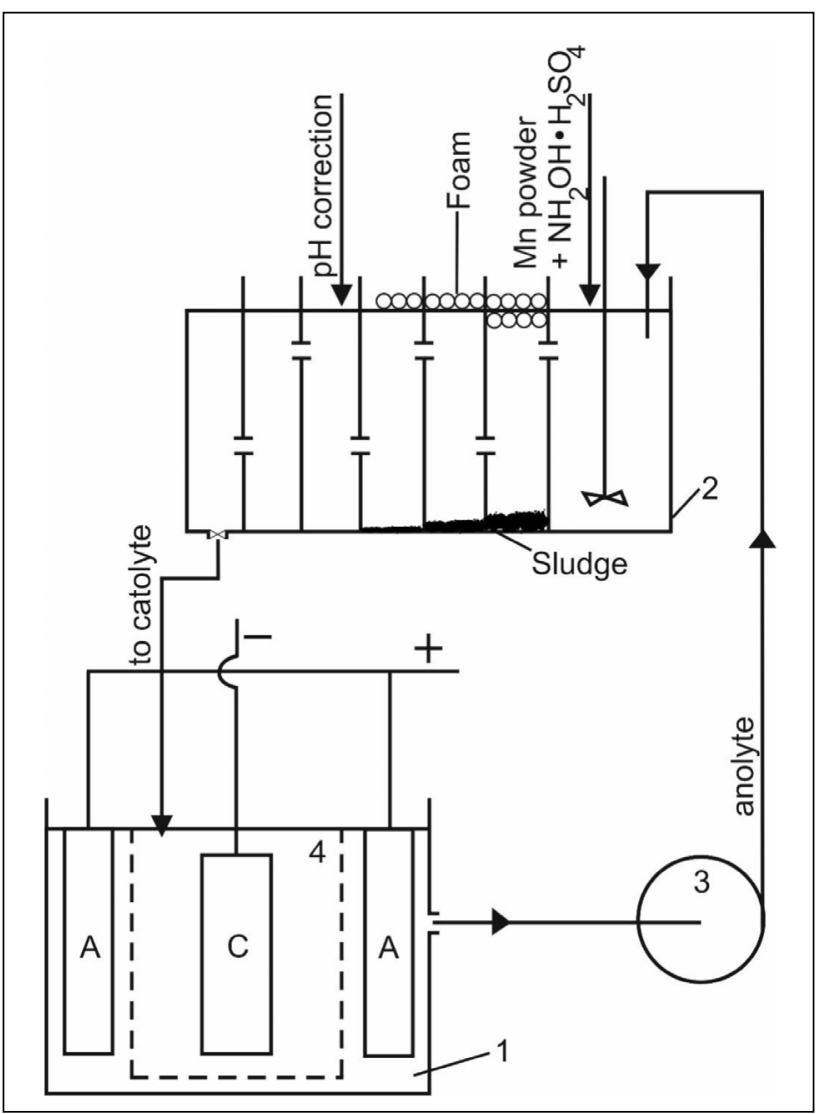

Fig. 7. Regeneration scheme $2: 1$, electrolysis bath; 2 , regenerator with a multisettler; 3 , pump; 4 , filtration element 
the compartment. On the surface of sections 2-4, a hydrogen foam released during the dissolution formed. In section 5, EMMP and insoluble products were finally dissolved and the electrolyte $\mathrm{pH}$ was adjusted. In section 7 , the electrolyte was finally settled and supplied to the cathode zone.

EMMP together with the hydroxylamine sulphate additive was poured into the regenerator periodically. In order to increase the dissolution rate of EMMP and to prevent the formation of insoluble Mn products, the mass of hydroxylamine sulphate was $10-15 \%$ higher than the mass of the electrodeposited Mn coating. The volume of the 1st section in the experiment was $15 \mathrm{~L}$. In order to thoroughly dissolve the EMMP and manganese oxide or hydroxide sediments and clear off the ME, the remaining 6 sections were 3-4 times larger than the volume of section 1. For improving the solubility of EMMP, the hydroxylamine sulphate additive must be used, and experiments showed that EMMP losses did not exceed 5-7\% from the mass of the electrodeposited Mn coatings on the cathode. These losses were estimated in the 1st section by adding EMMP. The regeneration efficiency, dissolution rate, and the quality of the electrodeposited Mn coatings were enhanced, when the cathodic zone in the electrolysis bath was separated from the anode zone by a diaphragm made from a compressed PVC tissue.

The $\mathrm{pH}$ of the produced ME was 3.9-4.0. Before use, the $\mathrm{pH}$ value of $\mathrm{ME}$ was adjusted to $6.9-7.0$ using 10-12\% aqueous ammonia. Adjustments of the electrolyte compo- nents was performed once per 8-hour shift. Ammonium selenate was dissolved by periodically (after each electrodeposition of the Mn coating on a specimen) dissolving $2 \%$ of the salt from the mass of the electrodeposited Mn coating on the cathode at an electrolyte temperature of 30$40^{\circ} \mathrm{C}$. The loss of ammonium sulphate was very slight. Once a week, the bath was cleaned and filtration elements and anodic coating were replaced optionally.

Operational conditions for electrodeposition manganese coatings using scheme 2 is summarized in Table 1 . Hard, brittle (Table 2), fine grained (Fig. 8) and smooth deposits of the $a-\mathrm{Mn}$ containing $0.63 \%$ Se mainly as $\mathrm{MnSe}$ (Fig. 9) were obtained.

The presence of oxygen in Mn coatings indicates the formation of oxide/hydroxide on the manganese surface. In

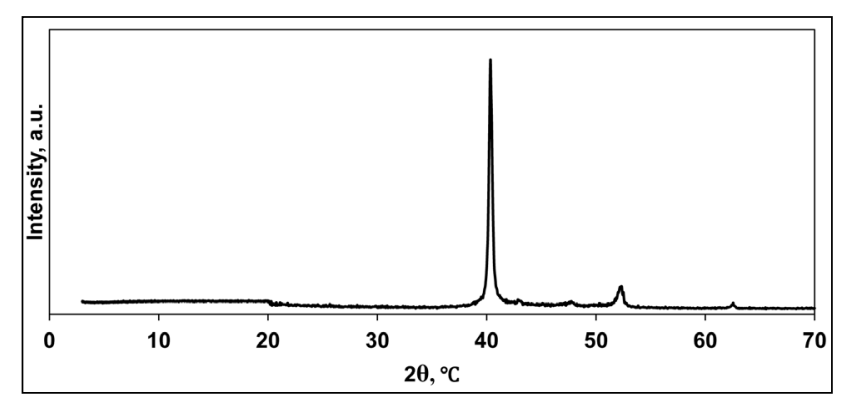

Fig. 8. XRD diffraction patterns of electrodeposited Mn coatings from ME at current density $j_{c}=10 \mathrm{~A} / \mathrm{dm}^{2}$ and $t=30^{\circ} \mathrm{C}$

Table 1. Operational conditions for electrodeposition of manganese coatings

\begin{tabular}{|c|c|c|c|c|}
\hline & \multicolumn{4}{|c|}{ Samples } \\
\hline & 1 & 2 & 3 & 4 \\
\hline $\mathrm{MnSO}_{4} \times 5 \mathrm{H}_{2} \mathrm{O} \mathrm{g} / \mathrm{L}$ & \multicolumn{4}{|c|}{180} \\
\hline$\left(\mathrm{NH}_{4}\right)_{2} \mathrm{SO}_{4}, \mathrm{~g} / \mathrm{L}$ & \multicolumn{4}{|c|}{170} \\
\hline$\left(\mathrm{NH}_{4}\right)_{2} \mathrm{SeO}_{4}, \mathrm{~g} / \mathrm{L}$ & \multicolumn{4}{|c|}{0.5} \\
\hline Conditions of electrolysis process & \multicolumn{4}{|c|}{$\mathrm{pH}=7.0 ; t=30^{\circ} \mathrm{C} ; j_{c}=10 \mathrm{~A} / \mathrm{dm}^{2}$} \\
\hline $\mathrm{NH}_{2} \mathrm{OH} \times \mathrm{H}_{2} \mathrm{SO}_{4}, \mathrm{~g} / \mathrm{L}$ & 0 & 0.5 & 2.0 & 5.0 \\
\hline Current efficiency, $\eta \%$ & 81 & 79 & 80 & 80 \\
\hline Mass of electrodeposited Mn coating, $\mathrm{g}$ & 149 & \multicolumn{3}{|c|}{132} \\
\hline Mass of EMMP, which was added to restore the initial concentration of $\mathrm{Mn}^{2+}$ & 198.5 & 169.1 & 139.0 & 138.0 \\
\hline Manganese losses during electrolysis, g & 49.5 & 37.1 & 7.0 & 6.0 \\
\hline Mass of added $\mathrm{NH}_{2} \mathrm{OH} \times \mathrm{H}_{2} \mathrm{SO}_{4}$ to $\mathrm{ME}, \mathrm{g}$ & 0 & 8.5 & 28.0 & 28.0 \\
\hline Duration of electrolyte concentration correction, $\mathrm{h}$ & \multicolumn{4}{|c|}{2} \\
\hline Concentration of manganese sulphate before correction, $\mathrm{g} / \mathrm{L}$ & 163.3 & 170.6 & 178.7 & 178.6 \\
\hline
\end{tabular}

Table 2. Microhardness (HV) and tensions ( $\sigma$ ) of Mn coatings electrodeposited at $j_{\mathrm{c}}=10 \mathrm{~A} / \mathrm{dm}^{2}$ and $t=30^{\circ} \mathrm{C}$

\begin{tabular}{|c|c|c|}
\hline Composition of ME & $\mathrm{HV}, \mathrm{MPa}$ & $\sigma, \operatorname{MPa}\left(d_{\text {average }^{\prime}} \mu \mathrm{m}\right)$ \\
\hline $\begin{array}{c}\left(\mathrm{NH}_{4}\right)_{2} \mathrm{SO}_{4} 125 \mathrm{~g} / \mathrm{L} \\
\mathrm{MnSO}_{4} \times 5 \mathrm{H}_{2} \mathrm{O} 150 \mathrm{~g} / \mathrm{L}\left(\mathrm{NH}_{4}\right)_{2} \mathrm{SeO}_{4} 0.5 \mathrm{~g} / \mathrm{L}\end{array}$ & $8371.1 \pm 715.6^{*}$ & $-4.81 \pm 0.56(25)$ \\
\hline
\end{tabular}

\footnotetext{
* The applied load was $0.49 \mathrm{~N} ;$ “"” compressive stresses.
} 


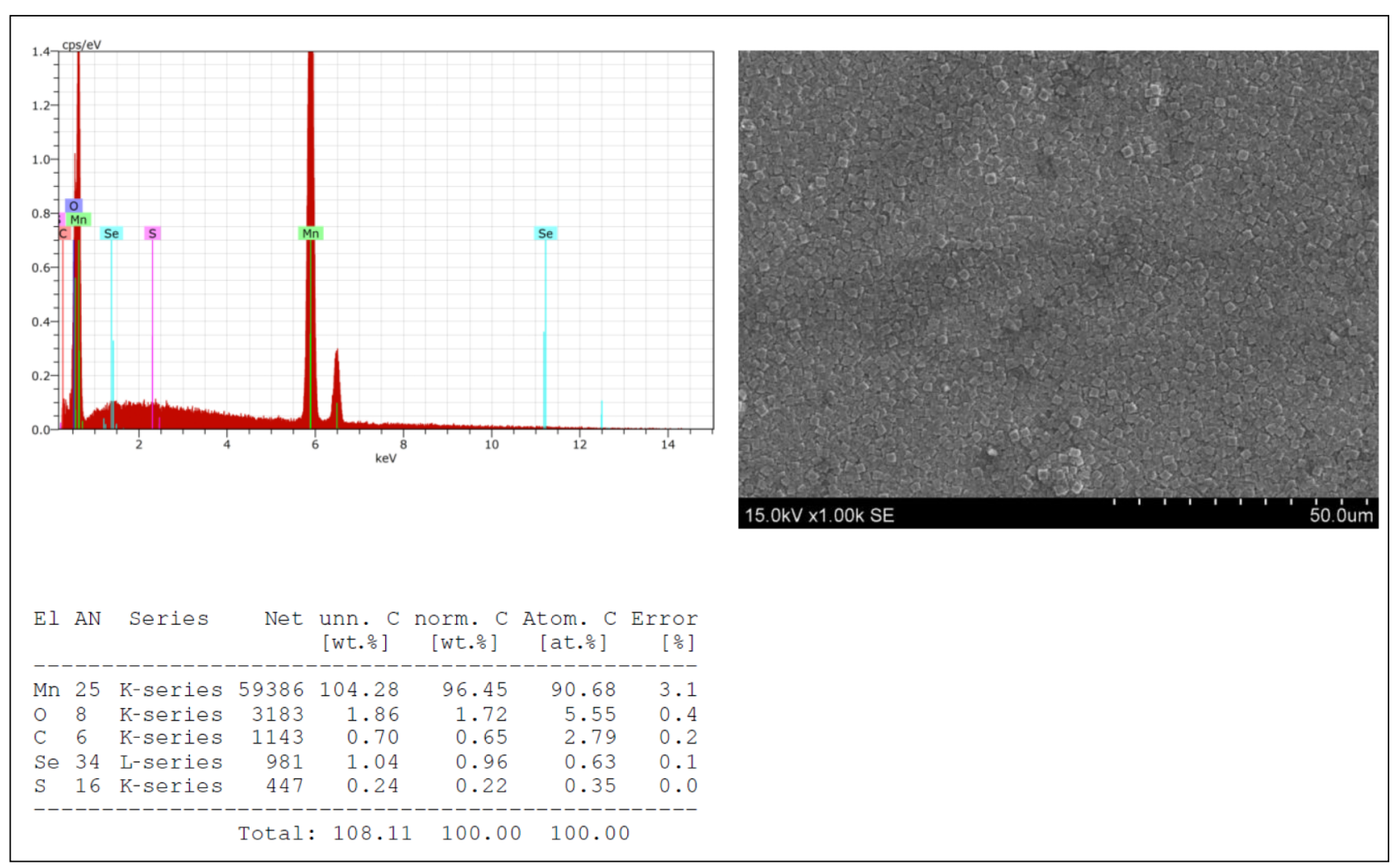

Fig. 9. The elemental composition of the electrodeposited after $12 \mathrm{~h}$ Mn coating determined by SEM with an elemental EDX analyser

aqueous electrolytes (sulfates or chlorides), electrodeposited $\mathrm{Mn}$ reacts with water, resulting in hydrogen evolution and formation of surface manganese oxide or hydroxide $\left(\mathrm{MnO}\right.$ or $\left.\mathrm{Mn}(\mathrm{OH})_{2}\right)$ [29].

The results of EDX showed that the amount of oxygen in the Mn coatings electrodeposited during 1-24 h and one week was increasing (5.55 and 9.64, respectively). This may be due to the fact that, over time, insoluble manganese compounds have produced in electrolyte that incorporate in $\mathrm{Mn}$ coating and its quality decreased. This shows that it is time to clean the filtration elements.

\section{CONCLUSIONS}

An environment-friendly regeneration method of manganese electrolyte (ME) that reduces the duration of the Mn coatings electrodeposition process and saves water resources for ME preparation was proposed. EMMP was dissolved in $\mathrm{ME}$ and a hydroxylamine sulphate additive significantly altered the dissolution effect of EMMP in ME.

The provided ME regeneration scheme allows one to extend duration of the Mn coating deposition process up to one week without changing the ME, but only by adding an electrolyte prepared by dissolving EMMP in an anolyte with $\mathrm{pH} 2.3$. High-quality a-Mn coatings with $80 \%$ of current efficiency were electrodeposited. EMMP losses did not exceed 5-7\% from the mass of the electrodeposited Mn coatings on the cathode. Ammonium selenate was dis- solved in ME by periodically dissolving $2 \%$ of the salt from the mass of the electrodeposited Mn coating on the cathode at an electrolyte temperature of $30-40^{\circ} \mathrm{C}$. The loss of ammonium sulphate was very slight. Once a week, the bath was cleaned and the filtration elements and anodic coating were replaced optionally.

Received 6 February 2018 Accepted 15 February 2018

\section{References}

1. J. A. M. Araujo, M. Castro, F. C. Lins, Hydrometallurgy, 84, 204 (2006).

2. N. Duan, Z. Dan, F. Wang, C. Pan, C. Zhou, L. Jiang, J. Clean Prod., 19, 2082 (2011).

3. Q. Wei, X. Ren, J. Du, S. Wei, S. R. Hu, Miner. Eng., 23, 578 (2010).

4. J. Lu, D. Dreisinger, T. Glück, Hydrometallurgy, 141, 105 (2014).

5. W. S. Zhang, C. Y. Cheng, Hydrometallurgy, 89, 160 (2007).

6. K. Hagelstein, J. Environ. Manag., 90, 3736 (2009).

7. X. M. Zhu, Y. S. Zhang, J. Mater. Sci. Lett., 6, 1516 (1997).

8. Manganese: The Fourth Most Used Metal in the World [http:// www.erametmarietta.com/manganese-the-fourth-mostused-metal-inthe-world2\#sthash.quIHBpyK.ueJRyxLs. dpbs].

9. J. Gong, I. Zana, G. Zangari, J. Mater. Sci. Lett., 20(21), 1921 (2001). 
10. P. Ilea, I. Popescu, M. Urda, L. Oniciu, Hydrometallurgy, 46, 149 (1997).

11. L. Y. Zhao, A. C. Siu, K. T. Leung, Chem. Mater., 19(26), 6414 (2007).

12. N. Galvanauskaite, A. Sulcius, E. Griskonis, P. Diaz-Arista, Trans. IMF, 89, 325 (2011).

13. M. Gonsalves, D. Pletcher, J. Electroanal. Chem., 285, 185 (1990).

14. J. Janickis, B. Stulpinas, J. Appl. Chem., 31, 225 (1958).

15. Y. Sun, X. K. Tian, B. B. He, et al., Electrochim. Acta, 56, 8305 (2011).

16. P. Wei, O. E. Hileman, M. R. Bateni, X. Deng, A. Petric, Surf. Coat. Technol., 201, 7739 (2007).

17. P. Patnaik, S. K. Padhy, B. C. Tripathy, M. K. Ghosh, I. N. Bhattacharya, Hydrometallurgy, 165, 73 (2016).

18. F. Xu, L. Jiang, Zh. Dan, et al., Hydrometallurgy, 149, 12 (2014).

19. N. Duan, F. Wang, C. Zhou, C. Zhu, H. Yu, Resour. Conserv. Recycl., 54, 506 (2010).

20. The Program for the Development of the Water Region 2017-2023, approved by the Lithuanian Government on 01.02.2017.

21. Z. Wei, A. Lafront, L. Xiao, E. Ghali, G. Houlachi, Innov. Corros. Mater. Sci., 5, 43 (2015).

22. M. Nicol, C. Akilan, V. Tjandrawan, J. A. Gonzalez, Hydrometallurgy, 173, 125 (2017).

23. J. J. McGinnity, M. J. Nicol, Hydrometallurgy, 144-145, 133 (2014).

24. Y. Q. Lai, Y. Li, L. X. Jiang, X. J. Lio, J. Li, Y. X. Liu, Hydrometallurgy, 115-116, 64 (2012).

25. R. Jaimes, M. Miranda-Hernández, L. Lartundo-Rojas, I. González, Hydrometallurgy, 156, 53 (2015).

26. W. Zhang, M. Bounoughaz, E. Ghali, G. Houlachi, Corros. Eng., 48(6), 452 (2013).
27. P. Alex, S. Majumdar, J. Kishor, I. G. Sharma, Mater. Sci. Appl., 2, 1307 (2011).

28. Ju. Tretjakov, L. Martinenko, A. Grigorjev, A. Civadze, Inorganic Chemistry. Chemistry of Elements, 2 edn., Akademkniga, Moscow (2007).

29. K. E. Heusler, M. Bergmann, Electrochim. Acta, 15(12), 1887 (1970).

\section{Algirdas Šulčius \\ MANGANO ELEKTROLITO REGENERAVIMAS VYKDANT NEPERTRAUKIAMĄ MANGANO DANGŲ ELEKTROLIZE}

\section{Santrauka}

Mangano ir amoniakinio azoto koncentracijos upėse, esančiose prie elektrolitinio mangano gamyklų, vis dar viršija standartus. Todèl vandens tarša elektrolitinio mangano pramonès gamybos procese yra rimta problema. Siūlomas ekologiškas manganavimo elektrolito regeneracijos laboratorijose metodas, kuris sumažina Mn dangų elektronusodinimo ir elektrolitui koreguoti skirtą trukmę bei taupo vandens išteklius, skirtus manganavimo elektrolitui paruošti. Elektrolitinio mangano milteliai buvo tirpinami manganavimo elektrolite, jų tirpimą labai pagerino hidroksilamino sulfato priedas. Pateikta manganavimo elektrolito regeneracijos schema leidžia pailginti Mn dangų elektronusodinimo trukmę iki vienos savaitės nekeičiant manganavimo elektrolito, o tik pridejjus naujas porcijas elektrolito, gauto ištirpinus elektrolitinio mangano miltelius anolite. Elektrolitinio mangano miltelių nuostoliai neviršijo 5-7 \% elektronusodinamų ant katodo Mn dangu masès. Amonio selenatas periodiškai buvo tirpinamas manganavimo elektrolite ir jo masė sudarè $2 \%$ druskos elektronusodinamų ant katodo Mn dangų $30-40{ }^{\circ} \mathrm{C}$ elektrolito masès. 